\title{
Rapid and visual detection of porcine deltacoronavirus by recombinase polymerase amplification combined with a lateral flow dipstick
}

Xiang Gao ${ }^{1,2}$, Xinsheng Liu' ${ }^{2}$ Yongguang Zhang ${ }^{2}$, Yanming Wei ${ }^{i^{*}}$ and Yonglu Wang ${ }^{2^{*}}$ (1)

\begin{abstract}
Background: Porcine Deltacoronavirus (PDCoV) is a newly emerging Coronavirus that was first identified in 2012 in Hong Kong, China. Since then, PDCoV has subsequently been reported worldwide, causing a high number of neonatal piglet deaths and significant economic losses to the swine industry. Therefore, it is necessary to establish a highly sensitive and specific method for the rapid diagnosis of PDCoV.

Results: In the present study, a highly sensitive and specific diagnostic method using recombinase polymerase amplification combined with a lateral flow dipstick (LFD-RPA) was developed for rapid and visual detection of PDCoV. The system can be performed under a broad range of temperature conditions from 10 to $37^{\circ} \mathrm{C}$, and the detection of PDCoV can be completed in $10 \mathrm{~min}$ at $37^{\circ} \mathrm{C}$. The sensitivity of this assay was 10 times higher than that of conventional PCR with a lower detection limit of $1 \times 10^{2}$ copies/ $\mu$ l of PDCoV. Meanwhile, the LFD-RPA assay specifically amplified PDCoV, while there was no cross-amplification with other swine-associated viruses, including Porcine epidemic diarrhea virus (PEDV), Transmissible gastroenteritis virus (TGEV), Porcine kobuvirus (PKoV), Foot and mouth disease virus (FMDV), Porcine reproductive and respiratory syndrome virus (PRRSV), Porcine circovirus type 2 (PCV2), Classical swine fever virus (CSFV) and Seneca valley virus (SW). The repeatability of the test results indicated that this assay had good repeatability. In addition, 68 clinical samples (48 fecal swab specimens and 20 intestinal specimens) were further tested by LFD-RPA and RT-PCR assay. The positive rate of LFD-RPA clinical samples was 26.47\% higher than that of conventional PCR (23.53\%).
\end{abstract}

Conclusions: The LFD-RPA assay successfully detected PDCoV in less than 20 min in this study, providing a potentially valuable tool to improve molecular detection for PDCoV and to monitor the outbreak of PDCoV, especially in low-resource areas and laboratories.

Keywords: Porcine Deltacoronavirus, Recombinase polymerase amplification, Lateral flow dipstick, Rapid diagnosis, Visual detection

\footnotetext{
* Correspondence: weiym@gsau.edu.cn; wangyonglumd@hotmail.com

${ }^{1}$ College of Veterinary Medicine, Gansu Agricultural University, Lanzhou 730070, China

${ }^{2}$ State Key Laboratory of Veterinary Etiological Biology, Key Laboratory of Animal Virology of the Ministry of Agriculture, Lanzhou Veterinary Research Institute, Chinese Academy of Agricultural Sciences, Lanzhou 730046, China
}

(c) The Author(s). 2020 Open Access This article is licensed under a Creative Commons Attribution 4.0 International License, which permits use, sharing, adaptation, distribution and reproduction in any medium or format, as long as you give appropriate credit to the original author(s) and the source, provide a link to the Creative Commons licence, and indicate if changes were made. The images or other third party material in this article are included in the article's Creative Commons licence, unless indicated otherwise in a credit line to the material. If material is not included in the article's Creative Commons licence and your intended use is not permitted by statutory regulation or exceeds the permitted use, you will need to obtain permission directly from the copyright holder. To view a copy of this licence, visit http://creativecommons.org/licenses/by/4.0/ The Creative Commons Public Domain Dedication waiver (http://creativecommons.org/publicdomain/zero/1.0/) applies to the data made available in this article, unless otherwise stated in a credit line to the data. 


\section{Background}

Porcine Deltacoronavirus (PDCoV) is an enveloped, single-stranded, positive-sense RNA virus and a member of the genus Deltacoronavirus in the family Coronaviridae that causes diarrhea, vomiting, dehydration and mortality in neonatal piglets [1-3]. The full genome of PDCoV is approximately $25.4 \mathrm{~kb}$ in length [2] and encodes genome arrangements in the following order: 5' untranslated region (UTR), open reading frame $1 \mathrm{a} / \mathrm{b}$ (ORF1a/b), spike (S), envelope (E), membrane (M), nonstructural protein 6 (NS6), nucleocapsid (N), nonstructural protein 7 (NS7), and 3' UTR [4]. PDCoV was first reported in pig feces collected in Hong Kong during the molecular surveillance for Coronavirus (CoVs) in avian and mammalian species in 2011 [2]. However, the first outbreak of PDCoV was announced in Ohio in 2014 [5]. Soon thereafter, PDCoV spread to several swineproducing states of the United States, causing mortality of $30 \sim 40 \%$ in neonatal pigs [6]. To date, PDCoV has been detected/ isolated in pigs across the world, including Canada [7], South Korea [8], China [9], Thailand [10], and Vietnam [11]. Additionally, PDCoV infection has become prevalent in pig farms around the world, which has caused enormous economic losses in multiple countries and remains a serious challenge to the swine industry $[12,13]$. At present, PDCoV is often seen in coinfection with other viral diarrheal pathogens with very similar clinical symptoms, which makes it difficult to effectively diagnose [14]. Furthermore, there are no effective vaccines or treatments for PDCoV, and the mechanism of its pathogenesis is still largely unknown [15]. Therefore, it is essential to develop a rapid, simple and highly sensitive diagnostic method to improve the efficacy of current control programs.

Recombinase polymerase amplification (RPA) is a novel isothermal DNA amplification technology that is remarkable due to its simplicity, high sensitivity, and compatibility with multiplexing, and is used for the detection of various infectious agents [16]. The RPA amplification product can be easily detected by lateral flow dipstick (LFD), where results are rapidly obtained in a visual read-out format [16]. Using this method, the products could be exponentially amplified in $30 \mathrm{~min}$ at a low and constant temperature, without the need for an initial denaturation step or the use of multiple primers $[17,18]$. In recent years, LFD-RPA has been used for the diagnosis of many pathogens, including Borrelia burgdorferi [19], Neospora caninum [20], Mycobacterium tuberculosis [21], Francisella tularensis [22] and Foot-andmouth disease virus [23]. In the present study, we developed a LFD-RPA diagnostic method that is simple, highly sensitive and specific for the rapid and visual detection of PDCoV in clinical fecal samples from pigs. This assay greatly reduces the time for detection and dependence on the experimental instrument and generates a potential improvement in the diagnosis of PDCoV.

\section{Results \\ Optimization of LFD-RPA conditions}

In the detection of PDCoV by the LFD-RPA assay, an intense test band could be observed on the lateral flow dipstick with the specific primers and probe. As shown in Fig. 1a, the LFD-RPA assay works well in the wide temperature range of 10 to $37^{\circ} \mathrm{C}$. Meanwhile, a light target band was detected in as little as $5 \mathrm{~min}$ after incubation in the $37^{\circ} \mathrm{C}$ metal bath, while there was no significant difference at 10, 15, 20, 25 and $30 \mathrm{~min}$ (Fig. 1b). Therefore, considering the detection specificity and efficiency, the amplification temperature and time of $37^{\circ} \mathrm{C}$ and $10 \mathrm{~min}$ may be the best reaction conditions for detecting PDCoV by LFD-RPA.

\section{LFD-RPA sensitivity}

To verify the sensitivity of LFD-RPA, a dilution series of standard plasmids ranging from $10^{9}$ to $10^{1}$ copies $/ \mu \mathrm{L}$ was used. The results demonstrated that the limit of detection with the LFD-RPA was $10^{2}$ copies/ $\mu \mathrm{L}$, which was higher than that of conventional PCR $\left(10^{3}\right.$ copies $\left./ \mu \mathrm{L}\right)$ (Fig. 2a and b).

\section{Detection specificity of LFD-RPA}

The specificity of LFD-RPA was evaluated by swineassociated virus (PDCoV, PEDV, TGEV, PKoV, FMDV, PRRSV, PCV2, CSFV and SVV). The results showed that the primers and probe used were specific for the amplification of PDCoV (Fig. 3), and there was no cross reaction with the other tested swine-associated viruses.

\section{Repeatability test}

The repeatability of the LFD-RPA assay was investigated using different standard control plasmids at concentrations $1 \times 10^{8}, 1 \times 10^{5}$ and $1 \times 10^{2}$ copies/ $\mu \mathrm{L}$ under the same conditions, and the assay exhibited the same results in inter- and intra-assay replicate experiments (Fig. 4).

\section{LFD-RPA performance compared with conventional PCR using clinical samples}

In a total of 68 clinical samples from subjects exhibiting diarrhea, the detection results indicated that the positive rate of the LFD-RPA method was $26.47 \%$, which was higher than that of the conventional PCR assay (23.53\%, Table 1).

\section{Discussion}

The LFD-RPA assay is a rapid, highly sensitive and selective detection method, and the results are obtained in 


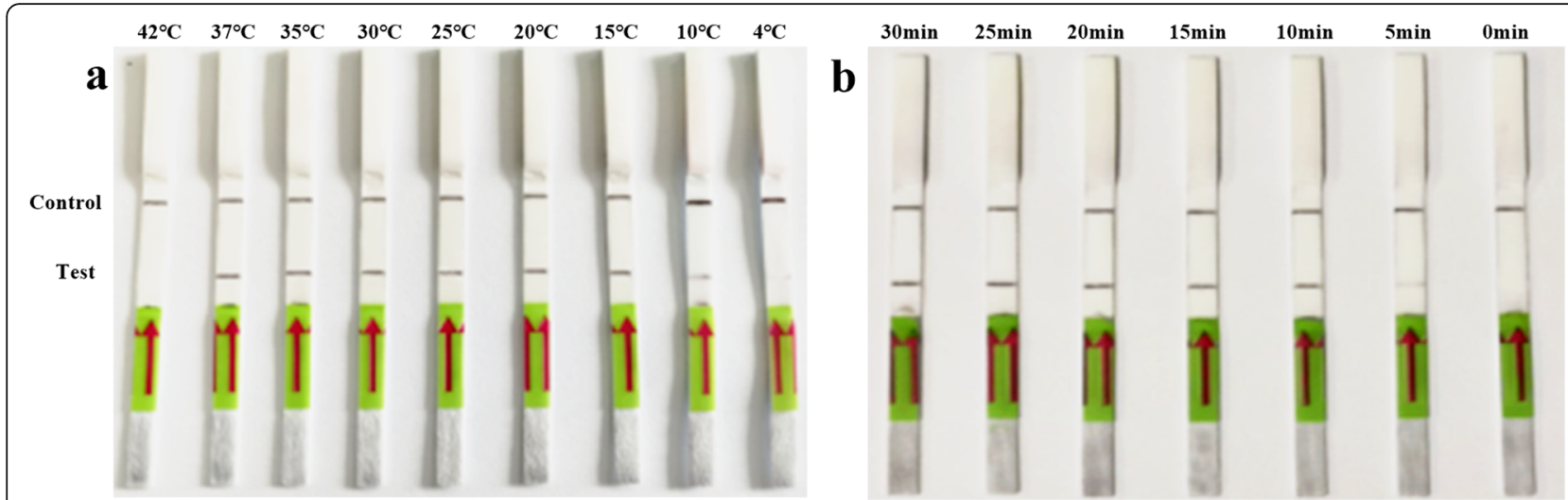

Fig. 1 Optimization of reaction temperature and time of the recombinase polymerase amplification combined with a lateral flow dipstick (LFDRPA) assay using $1 \times 10^{7}$ copies/ $\mathrm{LL}$ of recombinant plasmid DNA as a template. The top line on the lateral flow dipstick is the control line, and the next line is the test line. a Evaluation of different reaction temperatures from 4 to $42^{\circ} \mathrm{C}$ for $20 \mathrm{~min}$. $\mathbf{b}$ Evaluation of different reaction times between 0 and $30 \mathrm{~min}$ at $37^{\circ} \mathrm{C}$

a visual read-out format, which has been explored for the detection of diverse pathogens [16]. In the current study, we developed a rapid and visual method of LFDRPA for detecting PDCoV in clinical samples. It is much faster and more convenient than conventional RT-PCR. The LFD-RPA reaction can be accomplished in less than $20 \mathrm{~min}$ at $10-37^{\circ} \mathrm{C}$ without any expensive high precision instrumentation. This means that the reaction can operate efficiently at body temperature without the need for special equipment [24]. In addition, the detection limit of the LFD-RPA assay was $10^{2}$ copies/ $\mu \mathrm{L}$, which was more sensitive than the conventional RT-PCR $\left(10^{3}\right.$ copies $/ \mu \mathrm{L})$. Likewise, Ma et al. [25] recently reported a detection limit as low as $10^{2}$ copies/ $\mu \mathrm{L}$ of PDCoV by a real-time reverse transcription recombinase polymerase amplification (RT-RPA) assay, whose sensitivity was the same as that of LFD-RPA developed in the present study. The specific validation test indicated that the method is useful for PDCoV detection, and there was no cross-reaction with the several reference swine viruses used in the study. Moreover, the repeatability assay demonstrated that LFD-RPA has good repeatability for detecting PDCoV. Subsequently, LFD-RPA was used to detect the clinical samples to evaluate the performance. The results showed that the positive detection rate of LFD-RPA was higher than that of conventional RT-PCR, which indicating that LFD-RPA is capable of effectively and accurately detecting PDCoV. All the integrated data showed that LFD-RPA is a simple, visible, specific and sensitive tool for the rapid and accurate detection of PDCoV that is especially suitable for use in underequipped laboratories and at point-of-need facilities,

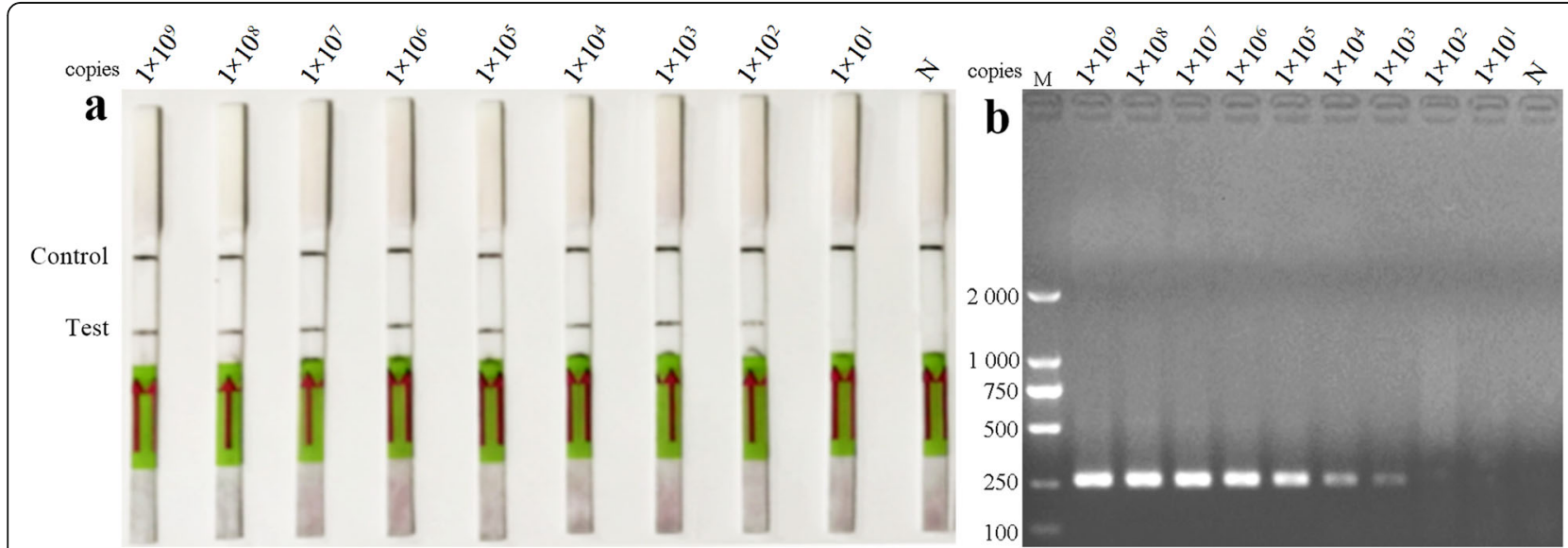

Fig. 2 Sensitivity of the LFD-RPA assay and conventional RT-PCR using 10-fold serial dilutions of standard control plasmids at concentrations ranging from $1 \times 10^{9}-1 \times 10^{1}$ copies/ $\mathrm{LL}$; previously tested PDCoV negative samples was used as a negative control. The top line on the lateral flow dipstick is the control line, and the next line is the test line. a Standard control plasmids at concentrations ranging from $1 \times 10^{9}-1 \times 10^{1}$

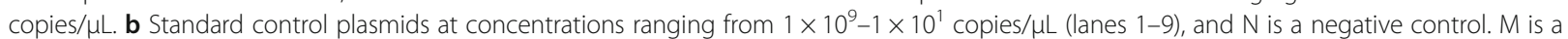
DNA marker 


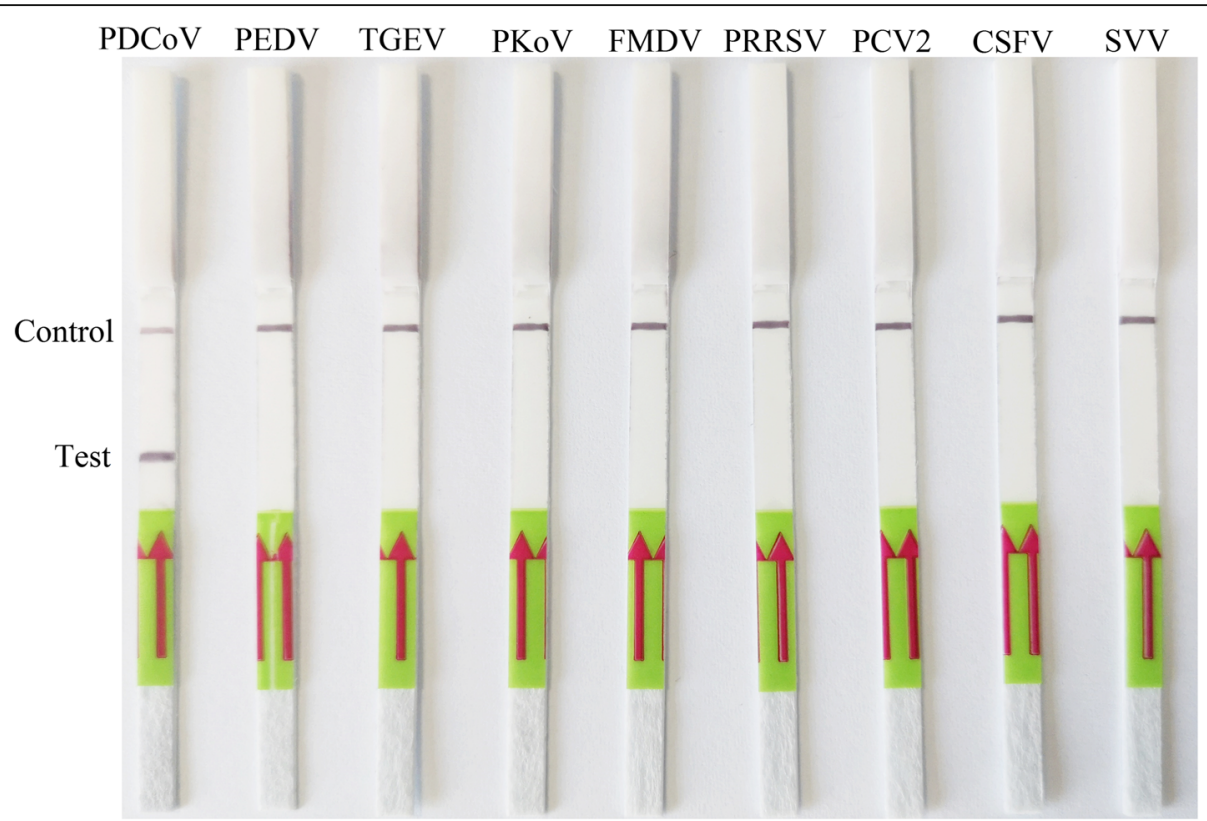

Fig. 3 Detection specificity of the LFD-RPA assay. The top line on the lateral flow dipstick is the control line, and the next line is the test line. Specificity of the LFD-RPA assay for different species of pig viruses, including Porcine Deltacoronavirus (PDCoV), Porcine epidemic diarrhea virus (PEDV), Transmissible gastroenteritis virus (TGEV), Porcine kobuvirus (PKoV), Foot and mouth disease virus (FMDV), Porcine reproductive and respiratory syndrome virus (PRRSV), Porcine circovirus type 2 (PCV2), Classical swine fever virus (CSFV) and Seneca valley virus (SW)

which is of great significance for PDCoV control in low resource settings.

Many relevant detection methods for PDCoV infections have been carried out, such as loop-mediated isothermal amplification (LAMP), indirect enzyme linked immunosorbent assay (ELISA), RT-PCR, and real-time RT-PCR [26-29]. However, those methods inherently require the use of specialized equipment and long reaction times, thus restricting their use in rapid detection and by low-resource laboratories. Although the LAMP assay is also an isothermal amplification technique that does not require expensive equipment, optimum reaction conditions that require a specific amplification temperature were performed at $63^{\circ} \mathrm{C}$ for $70 \mathrm{~min}$ and required five primers [26]. Furthermore, the results were visualized by adding SYBR Green I dye to

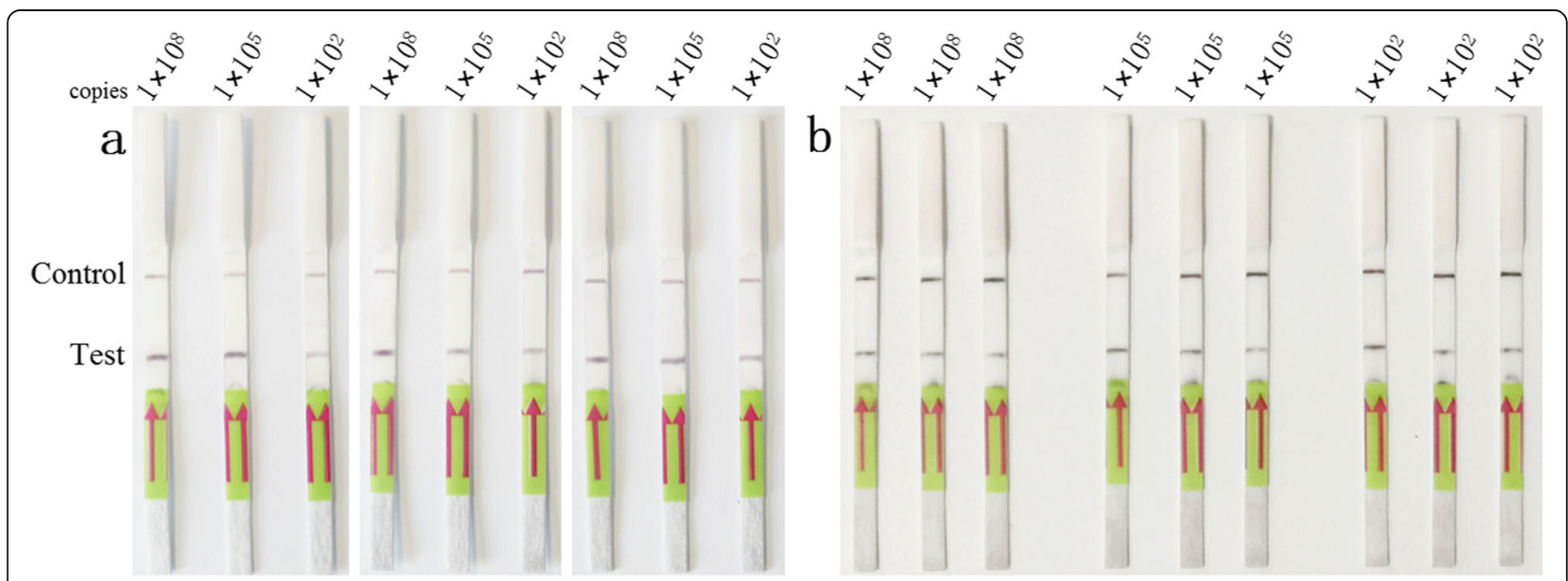

Fig. 4 Repeatability of the LFD-RPA assay. a Inter-assay repeatability test: The standard control plasmids, at concentrations $1 \times 10^{8}, 1 \times 10^{5}$ and $1 \times 10^{2}$ copies/ $\mu \mathrm{L}$ (lane $1-3$ ), were detected in three rounds under the same conditions. $\mathbf{b}$ Intra-assay repeatability test: The standard control plasmids, at concentrations $1 \times 10^{8}, 1 \times 10^{5}$ and $1 \times 10^{2}$ copies $/ \mu \mathrm{L}$, repeat three tests at the same time under the same conditions. The top line on the lateral flow dipstick is the control line, and the next line is the test line 
Table 1 Comparison of LFD-RPA and conventional PCR in clinical samples

\begin{tabular}{|c|c|c|c|c|c|}
\hline \multirow{2}{*}{$\begin{array}{l}\text { Samples } \\
\text { type }\end{array}$} & \multirow{2}{*}{$\begin{array}{l}\text { Number } \\
\text { of } \\
\text { samples }\end{array}$} & \multicolumn{2}{|l|}{ LF-RPA } & \multicolumn{2}{|c|}{ Conventional PCR } \\
\hline & & Positive & $\overline{\text { Negative }}$ & Positive & Negative \\
\hline fecal swab & 48 & 13 & 35 & 12 & 36 \\
\hline intestinal & 20 & 5 & 15 & 4 & 16 \\
\hline Total & 68 & 18 & 50 & 16 & 52 \\
\hline
\end{tabular}

the reaction tube [26]. Real-time RT-PCR and RT-PCR, which are simple methods for detecting PDCoV, have been developed with high sensitivity and specificity, but these assays are difficult to perform in resource-poor areas and are not appropriate for field detection of PDCoV $[25,30]$. Recently, a rapid and accurate real-time RT-RPA was established for the detection of PDCoV [25], while observations of results require specific equipment. However, compared with previous studies, LFDRPA was carried out at a lower temperature $\left(10-37^{\circ} \mathrm{C}\right)$, under a shorter time $(<20 \mathrm{~min})$ and required only a pair of primers in this study. In addition, the amplification product was visible on the LF dipstick inspected by the naked eye within $10 \mathrm{~min}$ and by untrained personnel. Furthermore, the LFD-RPA could also be easily performed in a water bath or even using body heat in field conditions, which favors the point-of-care detection of PDCoV and those scenarios involving a lack laboratory equipment. Thus, LFD-RPA offers significant benefits, and this method could be an ideal tool to improve the diagnostic efficiency and may contribute to effective surveillance of $\mathrm{PDCoV}$ in epidemical areas.

\section{Conclusions}

In summary, a highly sensitive and specific method was established to provide a more practical technique for the rapid and visual detection of PDCoV by RPA assay combined with LFD. This assay has the advantages of being simple, time-effective and inexpensive, which are comparatively applicable for underequipped laboratories as potential tools for preventing and controlling the spread of PDCoV.

\section{Methods}

\section{Sample collection and viruses}

A total of 68 clinical samples (48 fecal swab specimens and 20 intestinal specimens) were collected from piglets or pigs on different farms with acute diarrhea in six Chinese provinces during 2016-2017 and stored at $80^{\circ} \mathrm{C}$. Porcine Deltacoronavirus (PDCoV), Porcine epidemic diarrhea virus (PEDV), Transmissible gastroenteritis virus (TGEV), Porcine kobuvirus (PKoV), Foot and mouth disease virus (FMDV), Porcine reproductive and respiratory syndrome virus (PRRSV), Porcine circovirus type 2 (PCV2), Classical swine fever virus (CSFV) and
Seneca valley virus (SVV) were isolated from field samples and stored in our laboratory. PDCoV, PEDV and FMDV were tested by real-time RT-PCR in the study as positive controls, while the remaining viruses were detected by conventional PCR.

\section{Isolation of viral RNA and synthesis of CDNA}

The clinical samples were diluted 10-fold with serumfree Modified Eagle Medium (MEM, Invitrogen, USA) containing $1 \%$ penicillin-streptomycin $(10,000$ units $/ \mathrm{mL}$ of penicillin and $10,000 \mu \mathrm{g} / \mathrm{mL}$ of streptomycin, $\mathrm{Gibco}^{\mathrm{rm}}$, USA), vortexed, and centrifuged at $3500 \mathrm{rpm}$ at $4{ }^{\circ} \mathrm{C}$ for $30 \mathrm{~min}$. The viral RNAs were extracted from clinical samples using the Viral RNA Mini Kit (Qiagen, Germany), and reverse transcription was performed using the avian myeloblastosis virus reverse transcriptase kits (Promega, USA) in a total volume of $25 \mu \mathrm{L}$ according to the manufacturer's instructions and the reverse transcription procedure was $42^{\circ} \mathrm{C}$ for $1 \mathrm{~h}$. All cDNA samples were stored at $-20^{\circ} \mathrm{C}$ until use.

\section{Construction of molecular standard plasmid DNA}

The nucleocapsid $(\mathrm{N})$ gene of PDCoV (GenBank No: KJ481931) was selected as the targeted region of the RPA because the $\mathrm{N}$ gene is highly conserved among different isolates of PDCoV. The PCR amplification system was as follows: $2 \mu \mathrm{L}$ PrimeSTAR GXL DNA polymerase (TaKaRa, Dalian, China), $10 \mu \mathrm{L} 5 \times$ PrimeSTAR GXL Buffer, $4 \mu \mathrm{L}$ dNTP Mixture $(10 \mu \mathrm{M}), 2 \mu \mathrm{L}$ of each primer N-F/N-R (Table 2), and $3 \mu \mathrm{L}$ DNA template and $27 \mu \mathrm{L}$ double distilled $\mathrm{H}_{2} \mathrm{O}\left(\mathrm{ddH}_{2} \mathrm{O}\right)$. The temperature profile consisted of activation at $98^{\circ} \mathrm{C}$ for $3 \mathrm{~min}$ followed by 30 cycles of PCR at $98^{\circ} \mathrm{C}$ for $10 \mathrm{~s}, 60^{\circ} \mathrm{C}$ for $15 \mathrm{~s}, 68^{\circ} \mathrm{C}$ for $20 \mathrm{~s}$ and a final extension step at $68^{\circ} \mathrm{C}$ for $3 \mathrm{~min}$. The PCR products were purified with the PureLink ${ }^{\text {Th }}$ Quick Gel Extraction and PCR Purification Combo Kit (Invitrogen, Darmstadt, Germany) and then ligated into the pUC20-T vector (TaKaRa, Dalian, China) and translated into E. coli DH5 $\alpha$ cells (TaKaRa, Dalian, China). DNA concentrations were quantified using Thermo Scientific NanoDrop 2000 spectrophotometers (Thermo, Wilmington, USA). The quantity of DNA copies was calculated by the formula: DNA copy number (copies/ $\mu \mathrm{L})=\left(\mathrm{M} \times 6.02 \times 10^{23} \times 10^{-9}\right) /(\mathrm{n} \times 660)$, where $\mathrm{M}$ is molecular weight and $\mathrm{n}$ is the plasmid concentration $(\mathrm{g} / \mu \mathrm{L})$ measured at $260 \mathrm{~nm}$. Dilution of the copy number of the recombinant plasmid to $10^{9} \sim 10^{1}$ was performed to analyze sensitivity.

\section{Primer and probe design}

The N-specific primers and a probe for LFD-RPA were designed using Primer 3 V.4.0.0 (http://bioinfo.ut.ee) according to the TwistDx guidelines, with the reverse primer labeled with biotin at the $5^{\prime}$ end. The primers and 
Table 2 The primers and probe for conventional PCR and LFD-RPA assay used in this assay

\begin{tabular}{lllc}
\hline Assay & Primers and probe & Sequences 5'-3' & Amplicon size (bp) \\
\hline RPA & N-F & CGTCGTAAGACCCAGCATCAAGCTCCCAAGCGGAC & 257 \\
& N-R & GATTATGCTGTACCCTCGATCGT \\
LFD-RPA & LFD-F & CGTCGTAAGACCCAGCATCAAGCTCCCAAGCGGAC & 257 \\
& LFD-R & Biotin-GACTGTGATTGAGTAGGAGAAGGTAAGGGTAATTG \\
& LFD-Probe & FITC-GTCGGCTCTGGAGACACTGAGAAGACGGGT (THF)ATGGCTGATCCTCGCATCA-C3-Spacer \\
\hline
\end{tabular}

probe were synthesized by Takara company (Dalian, China). Detailed information on PDCoV LFD-RPA is listed in Table 2.

\section{Development of LFD-RPA assays}

The RPA assay was performed as described in the operation manual of the TwistAmp nfo Kit (TwistDx, Cambridge, UK). Briefly, each amplification mixture of the RPA assay with the following total volume of $50 \mu \mathrm{L}$ was as follows: $29.5 \mu \mathrm{L} 1 \times$ rehydration buffer, $2.4 \mu \mathrm{L}$ each primer LFD-F $(10 \mu \mathrm{M}) / \mathrm{LFD}-\mathrm{R} \quad(10 \mu \mathrm{M}), 0.6 \mu \mathrm{L}$ LFDprobe $(10 \mu \mathrm{M}), 2 \mu \mathrm{L}$ DNA template and $10.6 \mu \mathrm{L} d d \mathrm{H}_{2} \mathrm{O}$. For each sample, a total of $47.5 \mu \mathrm{L}$ of the mixture was added to dissolve the freeze-dried enzyme pellet, and the reaction started with $2.5 \mu \mathrm{L}$ of $280 \mathrm{mM}$ magnesium acetate. Then, the tubes were placed in a $37^{\circ} \mathrm{C}$ metal bath with constant shaking at $300 \mathrm{rpm}$ for $20 \mathrm{~min}$ [31]. Milenia Genline HybriDetect LFD strips (Milenia Biotec, Giessen, Germany) are a simple tool for quantitative, semi-quantitative and to some extent quantitative monitoring [32], used in this study to directly observe the results of RPA products. After incubation, the RPA products were diluted 1:10 with the assay buffer (supplied by the kit) and then LFD strips were inserted vertically into $200 \mu \mathrm{L}$ of diluted product at room temperature with the final result read within $10 \mathrm{~min}$. A positive result clearly showed a test line and control line, while the negative reactions only generated a control line.

\section{Optimization of LFD-RPA conditions}

The reaction temperature and time are two key parameters of LFD-RPA, which are optimized to improve detection efficiency. The LFD-RPA assay was tested on $1 \times 10^{7}$ copies $/ \mu \mathrm{L}$ of standard plasmid DNA as a template, and the optimum reaction was determined at different reaction temperatures: $4,10,15,20,25,30,35,37$ and $42^{\circ} \mathrm{C}$ for $20 \mathrm{~min}$. After identifying the optimal temperature, the reaction was performed for $0,5,10,15,20,25$ and $30 \mathrm{~min}$ at $37^{\circ} \mathrm{C}$ to determine the minimum amplification time required for the reaction.

\section{Sensitivity of LFD-RPA assay}

To determine the sensitivity of the LFD-RPA assay, 10fold serial dilutions were performed to obtain a gradient of standard plasmid DNA from $1 \times 10^{9}$ to $1 \times 10^{1}$ copies/ $\mu \mathrm{L}$ with nuclease-free water. Conventional PCR was used to compare sensitivity with the LFD-RPA assay, and previously tested PDCoV negative samples was used as a negative control. Therefore, $1 \mu \mathrm{L}$ diluted DNA was used as a template for LFD-RPA and then incubated at $37^{\circ} \mathrm{C}$ for $10 \mathrm{~min}$ with $300 \mathrm{rpm}$ constant shaking. The diluted DNA was also used in the conventional PCR reaction.

\section{Specificity of LFD-RPA assay}

Other common swine-associated viruses, such as PDCoV PEDV, TGEV, PKoV, FMDV, PRRSV, PCV2, CSFV and SVV were used to assess the specificity of the LFD-RPA assay under optimal conditions.

\section{Repeatability test}

To confirm the repeatability of the LFD-RPA assay, standard control plasmids at concentrations $1 \times 10^{8}, 1 \times 10^{5}$ and $1 \times 10^{2}$ copies $/ \mu \mathrm{L}$ were used. For inter-assay repeatability test, three independent tests were performed on three different days under the same conditions. For intraassay repeatability test, the same plasmid were tested three times at the same time under the same conditions.

\section{LFD-RPA performance compared with conventional PCR using clinical samples}

A total of 68 clinical samples (48 fecal swab specimens and 20 intestinal specimens) were collected from piglets or pigs on different farms with acute diarrhea in six Chinese provinces during 2016-2017. All samples were then examined for the presence of PDCoV by conventional PCR and LFDRPA to evaluate the detection efficiency of both assays. The conventional PCR volume $20 \mu \mathrm{L}$ system as follow: $1 \mu \mathrm{L}$ PrimeSTAR GXL DNA polymerase (TaKaRa, Dalian, China), $4 \mu \mathrm{L} 5 \times$ PrimeSTAR GXL Buffer, $2 \mu \mathrm{L}$ dNTP Mixture $(10 \mu \mathrm{M}), 1 \mu \mathrm{L}$ of each primer N-F/N-R (Table 2), and $1 \mu \mathrm{L}$ DNA template and $10 \mu \mathrm{L}$ double distilled $\mathrm{H}_{2} \mathrm{O}\left(\mathrm{ddH}_{2} \mathrm{O}\right)$. The temperature profile consisted of activation at $98^{\circ} \mathrm{C}$ for $3 \mathrm{~min}$ followed by 30 cycles of PCR at $98^{\circ} \mathrm{C}$ for $10 \mathrm{~s}, 60^{\circ} \mathrm{C}$ for $15 \mathrm{~s}, 68^{\circ} \mathrm{C}$ for $40 \mathrm{~s}$ and a final extension step at $68^{\circ} \mathrm{C}$ for $3 \mathrm{~min}$. Meantime, positive and negative controls were set up in PCR reaction and the positive bands of clinical samples were recovered for sequencing. The LFD-RPA assays were performed the same as those mentioned above. For each sample, the reaction was tested three times to determine whether a sample was positive or negative. 


\section{Abbreviations}

PDCoV: Porcine deltacoronavirus; PEDV: Porcine epidemic diarrhea virus; TGEV: Transmissible gastroenteritis virus; PKoV: Porcine kobuvirus; FMDV: Foot and mouth disease virus; PRRSV: Porcine reproductive and respiratory syndrome virus; PCV2: Porcine circovirus type 2; CSFV: Classical swine fever virus; SW: Seneca valley virus; LFD-RPA: Recombinase polymerase amplification combined with a lateral flow dipstick; RT-RPA: Reverse transcription recombinase polymerase amplification; RT-PCR: Reverse transcription polymerase chain reaction; UTR: Untranslated region; ORF: Open reading frame; CoVs: Coronavirus; MEM: Modified Eagle Medium; LAMP: Loop-mediated isothermal amplification; ELISA: Enzyme linked immunosorbent assay

\section{Acknowledgements}

Not applicable.

\section{Authors' contributions}

$X L, Y Z, Y W^{1}$ and $Y W^{2}$ conceived and designed the experiments. $X G$ and $X L$ wrote the manuscript and analyzed the data. $X \mathrm{~L}$ performed the sample collection. $X G$ and $X L$ performed the experiments. All authors read and approved the final manuscript.

\section{Funding}

This study was supported by the National Natural Science Foundation of China (Grant No. 31602095), the China Agriculture Research System (CARS37) and the Central Public Interest Scientific Institution Basal Research Fund (Y2016CG23). The funder played no role in the design as well as conclusion of the study.

\section{Availability of data and materials}

The datasets used and analyzed in the current study are available from the corresponding author upon reasonable request.

\section{Ethics approval and consent to participate}

Ethics approval all piglets used in the present study were humanely bred during the experiment and euthanized at the end of the experiment. Animal use and care protocols were reviewed and approved in writing by the Institutional Animal Use and Care Committee of Lanzhou Veterinary Research Institute. The farm owner received our oral notice of sample collection and completed the written consent statement of sample collection issued by the Institutional Animal Use and Care Committee of Lanzhou Veterinary Research Institute.

\section{Consent for publication}

Not applicable.

\section{Competing interests}

The authors declare that they have no competing interests.

Received: 24 April 2019 Accepted: 22 April 2020

Published online: 07 May 2020

\section{References}

1. Woo PC, Lau SK, Huang Y, Yuen KY. Coronavirus diversity, phylogeny and interspecies jumping. Exp Biol Med (Maywood). 2009;234:1117-27.

2. Woo PC, Lau SK, Lam CS, Lau CC, Tsang AK, Lau JH, et al. Discovery of seven novel mammalian and avian coronaviruses in the genus deltacoronavirus supports bat coronaviruses as the gene source of alphacoronavirus and betacoronavirus and avian coronaviruses as the gene source of gammacoronavirus and deltacoronavirus. J Virol. 2012;86:3995-4008.

3. Hu H, Jung K, Vlasova AN, Saif LJ. Experimental infection of gnotobiotic pigs with the cell-culture-adapted porcine deltacoronavirus strain OH-FD22. Arch Virol. 2016;161:3421-34.

4. Lee $\mathrm{S}$, Lee $\mathrm{C}$. Complete genome characterization of Korean porcine deltacoronavirus strain KOR/KNU14-04/2014. Genome Announc. 2014;2: e01191-14.

5. Wang $L$, Byrum B, Zhang $Y$. Detection and genetic characterization of deltacoronavirus in pigs, Ohio, USA, 2014. Emerg Infect Dis. 2014;20:122730 .
6. Jung K, Hu H, Saif LJ. Porcine deltacoronavirus infection: Etiology, cell culture for virus isolation and propagation, molecular epidemiology and pathogenesis. Virus Res. 2016;226:50-9.

7. Marthaler D, Raymond L, Jiang Y, Collins J, Rossow K, Rovira A. Rapid detection, complete genome sequencing, and phylogenetic analysis of porcine deltacoronavirus. Emerg Infect Dis. 2014;20:1347-50.

8. Lee JH, Chung HC, Nguyen VG, Moon HJ, Kim HK, Park SJ, et al. Detection and phylogenetic analysis of porcine deltacoronavirus in Korean swine farms, 2015. Transbound Emerg Dis. 2016;63:248-52.

9. Dong N, Fang L, Yang H, Liu H, Du T, Fang P, et al. Isolation, genomic characterization, and pathogenicity of a Chinese porcine deltacoronavirus strain CHN-HN-2014. Vet Microbiol. 2016;196:98-106.

10. Janetanakit T, Lumyai M, Bunpapong N, Boonyapisitsopa S, Chaiyawong S Nonthabenjawan N, et al. Porcine deltacoronavirus, Thailand, 2015. Emerg Infect Dis. 2016;22:757-9.

11. Le VP, Song S, An BH, Park GN, Pham NT, Le DQ, et al. A novel strain of porcine deltacoronavirus in Vietnam. Arch Virol. 2018;163:203-7.

12. Zhang J. Porcine deltacoronavirus: overview of infection dynamics, diagnostic methods, prevalence and genetic evolution. Virus Res. 2016;226: $71-84$.

13. Xu Z, Zhong H, Zhou Q, Du Y, Chen L, Zhang Y, et al. A highly pathogenic strain of porcine deltacoronavirus caused watery diarrhea in newborn piglets. Virol Sin. 2018;33:131-41.

14. Song D, Zhou X, Peng Q, Chen Y, Zhang F, Huang T, et al. Newly emerged porcine deltacoronavirus associated with diarrhoea in swine in China: identification, prevalence and full-length genome sequence analysis. Transbound Emerg Dis. 2015;62:575-80.

15. Xu Z, Zhong H, Huang S, Zhou Q, Du Y, Chen L, et al. Porcine deltacoronavirus induces TLR3, IL-12, IFN-alpha, IFN-beta and PKR mRNA expression in infected Peyer's patches in vivo. Vet Microbiol. 2019;228:226-33.

16. Lobato IM, O'Sullivan CK. Recombinase polymerase amplification: basics, applications and recent advances. Trends Analyt Chem. 2018;98:19-35.

17. Del Rio JS, Adly NY, Acero-Sanchez JL, Henry OY, O'Sullivan CK. Electrochemical detection of Francisella tularensis genomic DNA using solid-phase recombinase polymerase amplification. Biosens Bioelectron. 2014;54:674-8.

18. Daher RK, Stewart G, Boissinot M, Boudreau DK, Bergeron MG. Influence of sequence mismatches on the specificity of recombinase polymerase amplification technology. Mol Cell Probes. 2015;29:116-21.

19. Liu W, Liu HX, Zhang L, Hou XX, Wan KL, Hao Q. A novel isothermal assay of Borrelia burgdorferi by recombinase polymerase amplification with lateral flow detection. Int J Mol Sci. 2016;17:E1250.

20. Tian AL, Elsheikha HM, Zhou DH, Wu YD, Chen MX, Wang M, et al. A novel recombinase polymerase amplification (RPA) assay for the rapid isothermal detection of Neospora caninum in aborted bovine fetuses. Vet Parasitol. 2018;258:24-9.

21. Ma Q, Liu H, Ye F, Xiang G, Shan W, Xing W. Rapid and visual detection of Mycobacterium tuberculosis complex using recombinase polymerase amplification combined with lateral flow strips. Mol Cell Probes. 2017;36:43-9.

22. Euler M, Wang $Y$, Otto $P$, Tomaso H, Escudero $R$, Anda $P$, et al. Recombinase polymerase amplification assay for rapid detection of Francisella tularensis. J Clin Microbiol. 2012;50:2234-8.

23. Liu L, Wang J, Zhang R, Lin M, Shi R, Han Q, et al. Visual and equipment-free reverse transcription recombinase polymerase amplification method for rapid detection of foot-and-mouth disease virus. BMC Vet Res. 2018;14:263.

24. Crannell ZA, Rohrman B, Richards-Kortum R. Equipment-free incubation of recombinase polymerase amplification reactions using body heat. PLoS One. 2014;9:e112146.

25. Ma L, Zeng F, Huang B, Zhu Y, Wu M, Xu F, et al. Point-of-care diagnostic assay for rapid detection of porcine deltacoronavirus using the recombinase polymerase amplification method. Transbound Emerg Dis. 2019;66:1324-31.

26. Zhang F, Ye Y, Song D, Guo N, Peng Q, Li A, et al. A simple and rapid identification method for newly emerged porcine deltacoronavirus with loop-mediated isothermal amplification. Biol Res. 2017;50:30-7.

27. Okda F, Lawson S, Liu X, Singrey A, Clement T, Hain K, et al. Development of monoclonal antibodies and serological assays including indirect ELISA and fluorescent microsphere immunoassays for diagnosis of porcine deltacoronavirus. BMC Vet Res. 2016;12:95-107.

28. Hu H, Jung K, Wang Q, Saif L, Vlasova AN. Development of a one-step RTPCR assay for detection of pancoronaviruses (alpha-, beta-, gamma-, and delta-coronaviruses) using newly designed degenerate primers for porcine and avian fecal samples. J Virol Methods. 2018;256:116-22. 
29. Zhang J, Tsai YL, Lee PY, Chen Q, Zhang Y, Chiang CJ, et al. Evaluation of two singleplex reverse transcription-insulated isothermal PCR tests and a duplex real-time RT-PCR test for the detection of porcine epidemic diarrhea virus and porcine deltacoronavirus. J Virol Methods. 2016;234:34-42.

30. Ros-Garcia A, Nicolas A, Garcia-Perez AL, Juste RA, Hurtado A. Development and evaluation of a real-time PCR assay for the quantitative detection of Theileria annulata in cattle. Parasit Vectors. 2012;5:171.

31. Castellanos-Gonzalez A, Saldarriaga OA, Tartaglino L, Gacek R, Temple E, Sparks H, et al. A novel molecular test to diagnose Canine visceral leishmaniasis at the point of care. Am J Trop Med Hyg. 2015;93:970-5.

32. Posthuma-Trumpie GA. Korf J, Van amerongen a. lateral flow (immuno) assay: its strengths, weaknesses, opportunities and threats. A literature survey. Anal Bioana Chem. 2009;393:569-82.

\section{Publisher's Note}

Springer Nature remains neutral with regard to jurisdictional claims in published maps and institutional affiliations.

- fast, convenient online submission

- thorough peer review by experienced researchers in your field

- rapid publication on acceptance

- support for research data, including large and complex data types

- gold Open Access which fosters wider collaboration and increased citations

- maximum visibility for your research: over $100 \mathrm{M}$ website views per year

At $\mathrm{BMC}$, research is always in progress.

Learn more biomedcentral.com/submissions 